\title{
CZECH APPROACH TO IMPLEMENTATION OF ECOLOGICAL NETWORK
}

\author{
ANTONÍN BUČEK, PETR MADĚRA, LUBOŠ ÚRADNÍČEK
}

\begin{abstract}
Mendel University of Agriculture and Forestry, Department of Forest Botany, Dendrology and Geobiocoenology, Zemédělská 1, 61300 Brno, Czech Republic, email: bucek@ mendelu.cz,petrmad@mendelu.cz,uradnic@mendelu.cz
\end{abstract}

Received: $25^{\text {th }}$ April 2012, Accepted: $13^{\text {th }}$ June 2012

\begin{abstract}
An ecological network in the landscape consists of all existing and proposed landscape segments of ecological significance that can contribute to the conservation of landscape biodiversity. The concept of creation of territorial systems of ecological stability applied in the Czech Republic corresponds to the latest landscape ecological knowledge and landscape planning procedures used abroad. Biocorridors interconnect biocentres thus enable migration, interactions and permeability of landscape for organisms. Unlike biocentres, they don't need to provide for a permanent existence of all species of the represented communities. Thanks to the interconnection of biocentres by means of biocorridors there is an ecological network forming in the landscape. Development of the local biocorridor Vracov and the regional biocorridor Věstonice in south Moravia is presented.
\end{abstract}

Key words: ecological network, biocorridor development, primary succesion

\section{INTRODUCTION}

An ecological network in the landscape consists of all existing and proposed landscape segments of ecological significance that can contribute to the conservation of landscape biodiversity. Cultural landscapes are often miss a sufficient amount of these stabilizing elements. The observation became a basis for the Czech concept of creation of territorial systems of ecological stability in landscape as an integrated network of interconnected patches providing at least minimal spatial conditions for conservation of biodiversity (Buček, Lacina 1992). These ecologically significant landscape segments (territorial systems of ecological stability) are by their function subdivided into biocentres, biocorridors, buffer zones and interacting elements, and by their biogeographical significance (size, degree of biodiversity, representativeness, rarity or occurrence of endangered species and communities) classified at the following levels: local, regional, supra-regional, provincial, biospherical (Buček, Lacina 1996). Territorial systems of ecological stability in landscape are proposed according to five basic criteria: diversity of potential natural ecosystems, spatial relationship of biota in the landscape, spatial parameters, current state of the landscape, socioeconomic limits and intentions (Buček, Lacina, Míchal 1996). 
The concept of creation of territorial systems of ecological stability applied in the Czech Republic (Mackovčín 2000) corresponds with the latest landscape ecological knowledge and landscape planning procedures used abroad (see for example Jongman, Pungetti 2004, Boitani et al. 2011). Very similar concept is utilized in Slovakia (Ružičková, Šibl 2000). In Germany, there is a network of biotopes /Biotopvernetzung/ (Jedicke 1994) created in the landscape. In the Netherlands, a national ecological network /Ecologische hoofdstructuur/ (Lammers, Zadelhof 1996) is coming to existence. Some of the United States of America develop a network of biocorridors under the name of Greenways (Labaree 1992; Smith, Helmund 1993). In countries of the European Union, a pan-European ecological network is being gradually built within the EECONET (European Ecological Network) programme (Bennet 1994; 2004, Nowicki et al. 1996; Jongman 1998), consisting of a system of core areas - biocentres of European significance, interconnected by the means of biocorridors with adjacent zones of enhanced landscape management.

\section{METHODOLOGY OF CREATION OF TERRITORIAL SYSTEMS OF LANDSCAPE ECOLOGICAL STABILITY}

The objective of planning and developing territorial systems of ecological stability (TSES) in the Czech Republic is to stop the hitherto unfavourable trend in the development of ecological stability and to permanently provide for sustainable biological diversity in landscape. Czech Act no. 114/1992 Gaz. On nature conservation and landscape protection defines TSES as an interconnected system of both, natural and altered yet still near-natural ecosystems which maintain natural balance. According to this Act, the demarcation and assessment of TSES is one of the fundamental obligations in general nature conservation to be carried out by physical planning and nature conservation authorities in cooperation with institutions of water management, conservation of agricultural land resources and state administration of forest management. Protection of the system of ecological stability is mandatory for all owners and tenants of land properties forming its basis with its creation being a public concern shared by land owners, municipalities and government.

Most important components of the territorial systems are biocentres. Biocentre (the centre of biological diversity) is an area that should enable, due to its size and ecological conditions, permanent existence of species of natural genepools in landscape. Biocentres are demarcated to include a range of natural and man-made natural communities of agricultural landscape within a certain territory. Biocentres are further divided into those already existing and those planned. The already existing biocentres with natural and nearnatural ecosystems of a high degree of ecological stability have proven to be optimally functional across the entire demarcated area and this has to be the target state of all biocenters included in the territorial systems of ecological stability. A biocentre can be, for example, a natural oak wood, beech wood, scree-maple woods, herb-rich grasslands or ponds surrounded by wetland grass communities. In areas with shortage of remainders of natural and near-natural communities, biocentres must be newly created. Areas proposed in the landscape in TSES plans for the future establishment of a biocentre are referred to as proposed biocentres. At the present time, the territories of proposed biocentres can contain ecosystems with a low degree of ecological stability, heavily affected by human activity such as fields, Norway spruce monoculture or landfill sites. In the future, these areas will have to be transformed to provide conditions favourable for species of natural gene-pool in landscape. 
Biocorridors (biotic corridors) interconnect the biocentres thus enable migration, interaction and permeability of landscape fororganisms. Unlike biocentres they don't need to provide for a permanent existence of all species of the represented communities. Thanks to the interconnection of biocentres by means of biocorridors there is an ecological network forming in the landscape. The most continuous and high-density network of biocorridors in the rural landscape is formed by riparian stands stretching along water courses and streams, in which natural communities of willows, alders and ashes with the undergrowth of wetland and hydrophilic species often reach a length of several kilometers. In the intensively used agricultural landscape the function of biocorridors is fulfilled by newly planted forest belts and also by natural communities of hedgerows, stone mounds and agrarian terraces interconnecting biocentres. The importance of biocorridors varies for different groups of organisms in dependence on their various schemes of movement and ability to spread across the landscape. Similarly to biocentres, biocorridors are either existing or proposed in the TSES plans at places where new biocorridors will have to be established. Best functioning are continuous biocorridors consisting of natural communities with a high degree of ecological stability along their entire length. Functionality of biocorridors is conditioned by their space parameters (length and width), by the status of permanent ecological conditions, structure and species composition of biocoenoses (Smith, Hellmund 1993).

Basic types of TSES components at local level are the interaction elements. The term is used for small areas of natural communities with favourable conditions for the existence of some wildlife significantly affecting the functions of ecosystems in cultural landscape. Interaction elements are smaller in size than biocentres and biocorridors and are often spatially isolated. Typical interaction elements are, for example, shrub communities on forest edges, game refuges in fields and communities of hardwood in coniferous monocultures.

Planning of territorial systems of ecological stability is based on diversity of potential natural ecosystems, i.e. on diversity of communities that would have developed in the landscape without the impact of anthropogenic activities. The diversity of natural ecosystems in a certain landscape depends on diversity of permanent ecological conditions, namely on the character of geological bedrock, relief, soils and climate. The diversity of potential natural ecosystems in landscape is described in the typological map of geobiocoene type groups (Buček, Lacina 1999). The representation of existing communities occurring in the skeleton of ecological stability shows if the biocentres contain all characteristic geobiocoene types and what communities are to be added and newly created in the territorial system. The location of biocentres and biocorridors is prefered as continuous interconnection of biocentres with identical or similar communities. The most difficult and at the same time the most important task was to set spatial parameters. Using all the available scientific knowledge, the experts in the thirty-member team arrived in the end at a compromise solution in the search for the minimum spatial parameters necessary for the function of biocentres and biocorridors. The parameters (area, length and width) vary obviously according to the level of significance of the territorial system. The area required is smallest in local systems and increases on, moving from regional to supra-regional systems(Buček, Lacina 1996).

\section{Case study 1: The Vracov local biocorridor development}

One of the first plantations of elements of the local TSES implemented in South Moravia within the Programme of Environment Revitalization funded by the Ministry of Agriculture 
after the year 1990 was the biocorridor of Vracov (Úradníček 2004). Regarding the fact that there was no previous experience with the design in the Czech Republic, planting and growth of these green belts on arable land, the study aimed at an assessment of the biocorridor woody component development at the initial stage, particularly at a growth of woody species on the formerly used rural land, and at evaluation of changes in the species composition during the period under study.

The reseach was made in the local biocorridor of Vracov which is situated in South Moravia, Hodonín district, cadastral area Vracov. Being established in 1991, the biocorridor runs perpendicullary to the main motorway from Kyjov to Veselí nad Moravou, some $2 \mathrm{~km} \mathrm{NW}$ of Vracov. Its total length is $1,830 \mathrm{~m}$, width $15 \mathrm{~m}$. It was planted in a territory with no original vegetation, on arable land. Target community is to be of the forest environment character. The biocorridor is located in the warmest part in the Czech Republic, with expressively warm climate of medium to mild humidity (mean annual temperatures $9.1^{\circ} \mathrm{C}$, precipitation $569 \mathrm{~mm} / \mathrm{yr}$ ), growing period about 165 days. Poor in nutrients sands are dominated by light unsaturated arenic Cambisols up to acidic Rankers, which pass into arenic Chernozems at places with a greater admixture of clayey and loamy loes fractions. Parent rock consists of terrace gravel-sands of the Morava River, with drift sands dwelling on them. Marginally, there are alluvia, peat bogs and moors of Vracov, partly calcareous. Typical are water-logged interdune depressions (Culek 1996).

Evaluation of the growth of individual woody species was carried out in 1993-2007 on permanent research plots (PRP). There were 4 PRPs aligned in the fenced biocorridor, each of $50 \mathrm{~m}$ in length and $16 \mathrm{~m}$ in width. Each of PRPs have 8 rows at an average distance of 2 $\mathrm{m}$, row spacing is $1.0-1.6 \mathrm{~m}$ in dependence on woody species. Total number of trees monitored on the PRPs was about 1,100. The PRP4 was used as an example here only.

Complete inventories of the entire biocorridor were carried out in 1996, 2002 and 2007. In addition to the initially planted woody species, natural regeneration was recorded of both vegetative and generative origin.

$P R P \quad 4$ is situated near a road connecting the villages of Vracov and Vlkoš, easily accessible, with a possibility of short excursions. The skeleton species of Quercus robur represented by 34 individuals - exhibited a more rapid growth, average tree height increased from the original $1.45 \mathrm{~m}$ in 1993, by $15.68 \mathrm{~m}$ in 2007 (Jelínek, Úradníček 2010). It reached average year height increment $106.6 \mathrm{~cm}$ in described period. Average diameter was $14.02 \mathrm{~cm}$. The species did not display any game damage, the trees are already grownup and any danger to their development is not to be expected. Tilia cordata was another species to exhibit a considerable increase of average tree height and diameter. In 2007 lime trees were higher than oaks, their average tree height being $16.59 \mathrm{~m}$ (Fig. 1). Comparing with oak, lime reached lower average year height increment $-93.8 \mathrm{~cm}$. Cerasum avium achieves excellent growth parameters on this plot, too. Its average tree height was $13.3 \mathrm{~m}$ and the tallest individual reaches up to a height of $17.4 \mathrm{~m}$. Diameter at breast height of the most sizeable cherry tree was $30.43 \mathrm{~cm}$. Sizeable are also trees of Padus racemosa average tree height $9.06 \mathrm{~m}$. Shrub layer once again consists mainly of the species Cornus sanguinea, average height increased from the original $116.1 \mathrm{~cm}$ in 1993 , by $218.2 \mathrm{~cm}$ in 2007, reaching $349.2 \mathrm{~cm}$. 
Fig. 1: Averige height of oak and lime tree

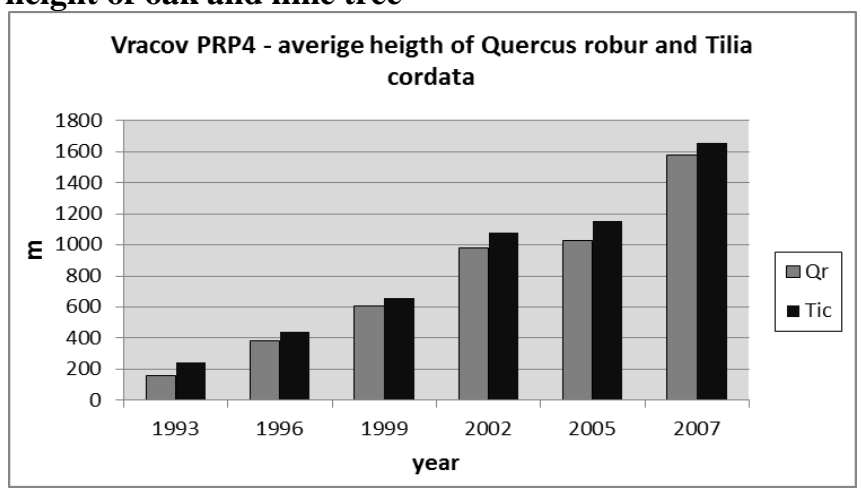

Open areas of the plot exhibit a more intensive natural regeneration of woody species such as Sambucus nigra or Cerasus avium; suckers and self-seeding of Rosa multiflora were found here similarly as on other plots. The road vicinity affects the plot in a negative way and there is even an illegal landfill here. This part of the biocorridor is occasionally entered by wildlife as well but the busy traffic on the road would not encourage the animals to do so and the losses on woody species due to game are nearly negligible. The greatest damage was recorded in the species of Rhamnus cathartica and Cornus sanguinea. Some species suffered a mechanical damage by humans. The amount of woody plants is decreasing in last years, see Tab 1.

Table 1: Number of woody plants on PRP 4

\begin{tabular}{|l|c|c|c|c|c|c|}
\hline \multirow{2}{*}{ Species on PRP 4 } & \multicolumn{7}{c|}{ number of plants (pcs) in year } \\
\cline { 2 - 7 } & 1993 & 1996 & 1999 & 2002 & 2005 & 2007 \\
\hline Acer campestre - ACC & 47 & 45 & 41 & 36 & 29 & 20 \\
\hline Cerasus avium - CA & 41 & 41 & 40 & 38 & 38 & 38 \\
\hline Corylus avellana - COR & 7 & 7 & 6 & 7 & 9 & 6 \\
\hline Cornus sanguinea - COS & 38 & 38 & 38 & 38 & 38 & 29 \\
\hline Ligustrum ovalifolium - LIGO & 93 & 93 & 83 & 33 & 10 & 3 \\
\hline Lonicera tatarica - LOT & 3 & 3 & 3 & 3 & 3 & 0 \\
\hline Padus racemosa - PAD & 31 & 31 & 33 & 31 & 27 & 28 \\
\hline Populus tremula - POT & 1 & 1 & 1 & 1 & 1 & 1 \\
\hline Prunus spinosa - PS & 3 & 3 & 3 & 3 & 4 & 3 \\
\hline Quercus robur - QUR & 38 & 38 & 34 & 34 & 33 & 33 \\
\hline Rhamnus cathartica - RHC & 3 & 3 & 3 & 3 & 1 & 0 \\
\hline Rosa multiflora - ROM & 3 & 0 & 4 & 3 & 2 & 0 \\
\hline Sorbus aucuparia - SOAU & 1 & 1 & 1 & 1 & 1 & 0 \\
\hline Tilia cordata - TIC & 8 & 8 & 8 & 8 & 8 & 8 \\
\hline Viburnum lantana - VL & 8 & 7 & 6 & 6 & 6 & 6 \\
\hline Total & 325 & 319 & 304 & 245 & 210 & 175 \\
\hline
\end{tabular}

The whole linear community was subjected to an assessment of 11,072 specimens of woody species in the year 2002. The inventory detected in this locality as many as 32 taxa of both domestic and introduced woody species, i.e. by 4 species less than in 1996. Results were compared with the inventory made in 2007 (Table 2). Full inventory exceeds the limited requirements of this paper.

It was concluded at this research once again that in the biocorridor which should contain only native -preferably autochthonous- woody species, there is a great number of non- 
autochthonous (introduced) species. Nevertheless, the situation has improved since the year 1996. The representation of non-autochthonous species in 1996 was 4,594 individuals (35\% of all woody species occurring in the biocorridor). In 2007, the occurrence of the introduced species decreased to 1,931 individuals ("only" $20.5 \%$ of all woody species occurring in the biocorridor); this indicates that in the course of 10 growing seasons the representation of introduced woody species was reduced by $15 \%$. The largest decrease was observed in the Asian species Ligustrum ovalifolium, more than 50\%. The monitoring included also natural regeneration of woody species. The highest number of woody species from self-seeding was found in the species of Sambucus nigra-over 200 individuals.

The layer of woody species in the biocorridor Vracov is gradually achieving enclosed canopy and shaded individuals are observed to die, this is why the total number of trees is decreasing. The tree storey (Quercus robur, Tilia cordata, Acer campestre, etc.) is properly grown-up which means that the skeleton of the linear community is stable. The shrub layer and fillers are at many places heavily crowded, cramped, not allowing the succession of other woody species and especially herbs, preventing the development of a greater species diversity in the biocorridor. Additional planting is not necessary so far since the original planting was too dense and oversized with respect to the growth of individual species used.

Table 2: General inventory

\begin{tabular}{|l|c|c|c|}
\hline $\begin{array}{l}\text { Woody plants } \\
\text { (in sum) }\end{array}$ & $\begin{array}{c}1996 \\
12970\end{array}$ & $\begin{array}{c}2002 \\
11072\end{array}$ & $\begin{array}{c}2007 \\
9464\end{array}$ \\
\hline Autochthonous & 8435 & 8276 & 7533 \\
$(\%)$ & 65 & 75 & 79,5 \\
\hline Introduced & 4535 & 2796 & 1931 \\
(allochthonous) & 35 & 25 & 20,5 \\
$(\%)$ & & & \\
\hline
\end{tabular}

Although the inventory revealed a larger amount of non-autochthonous species in the woody species composition - such as Ligustrum ovalifolium, taxa of the genus Lonicera, which should not occur in the planting - the biocorridor developed very well in the period under study. At this stage of thedevelopment of the biocorridor, when the number of woody species is observed to fall, it is necessary to see that the stock of non-autochthonous species is decreasing and the stock of domestic species is supported and maintained. The studied Permanent Research Plots exhibit an obvious development of the skeleton species, which provides good pre-requisites for the future of the biocorridor. It can be concluded that nearly all woody species grow very well and the biocorridor is fully enclosed. There is no danger of considerable game damage, the process of regeneration occurs rapidly with the biomass increment being high enough to resist any game damage. The condition of the biocorridor can be generally evaluated as very good. At this stage of development, the biocorridor is already capable of fulfilling the required functions.

\section{Case study 2: The regional biocorridor Věstonice development}

The hydroengineering structure of Nové Mlýny was built in 1975-1989 within the framework of complex hydrotechnical regulations in South Moravia. It consists of three lakes of which the middle one was proclaimed the Nature Reserve of Věstonická nádrž (Věstonice Water Reservoir) due to the occurrence and nesting of numerous waterfowl 
species. The middle water reservoir of the Nové Mlýny hydroengineering structure is situated some $40 \mathrm{~km}$ south of Brno on the former confluence of the rivers Svratka, Jihlava and Dyje. Seen from the viewpoint of landscape ecology, however, the hydroengineering structure on the confluence of the Dyje, Jihlava and Svratka Rivers disrupted the connectivity of floodplain biotopes between the Dyje-Svratka R. and the Dyje-Morava R. alluvial plains. Rare biotopes of floodplain forests, alluvial meadows, bog wetlands, riverine lakes, meandering water courses and xerotherm communities of sand dunes ceased to exist under the water surface of the reservoir (Packová, Maděra 2005).

After 1989, the Ministry of Environment of the Czech Republic adopted a policy for the ecological enhancement of the Nové Mlýny middle reservoir within the framework of which the water level was lowered in July 1996 by $85 \mathrm{~cm}$ to a spot height of $169.50 \mathrm{~m}$ a.s.l. and a construction of two artificial islands was launched that would serve as a part of the regional biocorridor (Forman 1983; Buček, Lacina 1996) running through the floodplain. The islands are meant to abridge the distance over the reservoir water surface which is for many organisms too large to pass.

The lowering of the water level caused denudation of sediment loads in the Jihlava and Svratka Rivers mouth tracks, enlargement of the existing holms area in the reservoir and denudation of border dam bases - all this on an area of several tens of hectares. Flamiková (1996) mentions approximately 70 ha of newly denudated surfaces. These newly denudated surfaces provided optimal conditions for the oecesis of soft floodplain communities. At the time of water surface lowering in July 1996, seeds of soft floodplain tree species could not have been any longer present in the air, especially those of anemochoric willows. Nevertheless, seedlings of white willow, black poplar and interspersed seedlings of other willow species emerged on the sediment loads in high population densities of up to 45 individuals per a square meter (Kovářová 2003).

The study aims at the description of the oecesis, i.e. establishment of white willow communities on the approximately 80 ha of denudated sediment loads (Fig.2) as the experience may be utilized in similar revitalization measures in alluvial plains.

Fig. 2: The map of denudated plots in the NR Věstonická nádrž Reservoir after the water level lowering to a spot height of $169.50 \mathrm{~m}$ a.s.l.

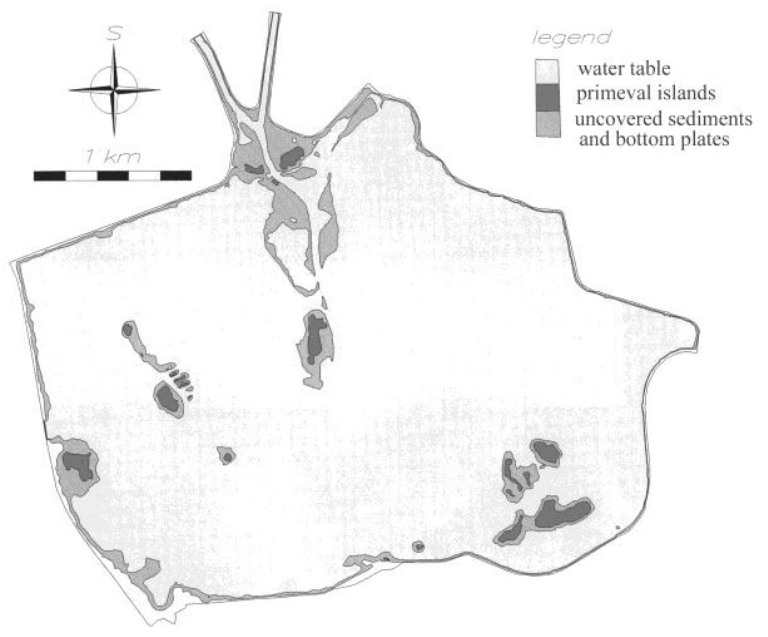


Vitality of white willow seeds is described as very short in literature. If the seeds fail to find a suitable place for germination, they would lose their germinative capacity within a few days (Chmelař, Meusel 1986). White willow is ranked in the group of species with an orthodoxically short viability of seeds also by Maroder et al. (2003). Our experiments show that the seeds can keep a nearly $100 \%$ germinative capacity for 3 days that are followed by a rapid decrease. The last seeds germinated after 17 days of dry storage. This indicates that the above mentioned advance growths could not have emerged from a seed bank. According to our phenological observations, in 2003, the fruits of white willow in the area of the middle reservoir started to ripen on 23 May while in 2004 the capsules ripened after a very cold month of May as late as from 5 June. The seed rain duration was two weeks in the both years. It was retrospectively documented that the rain of seeds lasted until max. 20 June also in 1996, and that the oecesis of seeds was not likely to have had occurred by means of the seed rain. In what way did white willow communities oecesis in nature reserve Věstonická nádrž continue?

A working hypothesis was that seeds fallen into water at the time of seed rain would keep a longer germinative capacity than seeds fluttering in the air and fallen on the ground. Hence, that an analogy exists to the soil bank of seeds also in water - as a water seed bank composed of hydrochoric plant species, whose function -apart from the displacement of diaspores- consists also of the extension of seed vitality and thus in an enhanced chance for the plant establishment.

However, the reality was quite different. According to our field trials (Maděra, Svobodová, Packová 2009), the seeds stored in the water germinated promptly and seedlings lived on more than 40 days. The oecesis was made thanks to ,a seedlings waterbank". The seedlings were washed up on the uncovered depositions and lakesides. The white willow behaves in juvenile phase in water as a natant or submerged hygrophyte species and prolongs its ability to occupy a new territory.

This explains why there were seedlings remaining on the denudated sediment loads and embankments during the gradual lowering of the water level in July 1996, or deposited there by means of surge, which would also explain the presence of white willow communities in a more or less broad strip (up to $60 \mathrm{~m}$ ) along the banks. Grassland and herbaceous communities were developing at a greater distance from the banks.

The next development of succession processes was monitored in 40 permanent research plots of an area $5 \times 5 \mathrm{~m}$ based in different distance perpendicular to the bank line (Maděra, Packová 2004).

The described initial seral stages of willow-poplar alluvial forests are very monotonous in terms of their species composition with an absolute dominance of willows and prevailing traits of Salix alba L., only exceptionally with individuals classified as belonging in the genus Salix x rubens $\mathrm{S}$ ch r. In addition to the genus of Salix, the oecesion also included Populus nigra L. Which, however, gradually fell out from the community (60-day flooding of seedlings in 1997) so that only 21 individuals were found in 2002 to occur on an area of 6.3 ha (Buček et al. 2002), and none of them was detected on the research plots.

The population density in the community decreases with the increasing distance from the bank line with the average size of individuals growing at the same time. The fact is well documented also by diagrams in Figs 3 and 4. The groundwater table decreases with the increasing distance from the bank line. A variance of several centimeters in the ground water table has a pronounced beneficial influence on the growth of individuals. However, the larger the physiological depth of soil, the greater the intraspecific competition. The phenomenon has a response in an intensive self-thinning, which can be documented by a close dependence of stem diameter and density of individuals illustrated in graph see Fig. 
5. From the germination of seedlings in 1996, mortality in the year 2002 reached up to $95 \%$ on plots which were most distant from the bank line. This mortality of individuals was certainly affected also by the 60-day flooding occurring in July and August 1997.

Fig. 3: Dependence of white willow tree height on the bank line distance

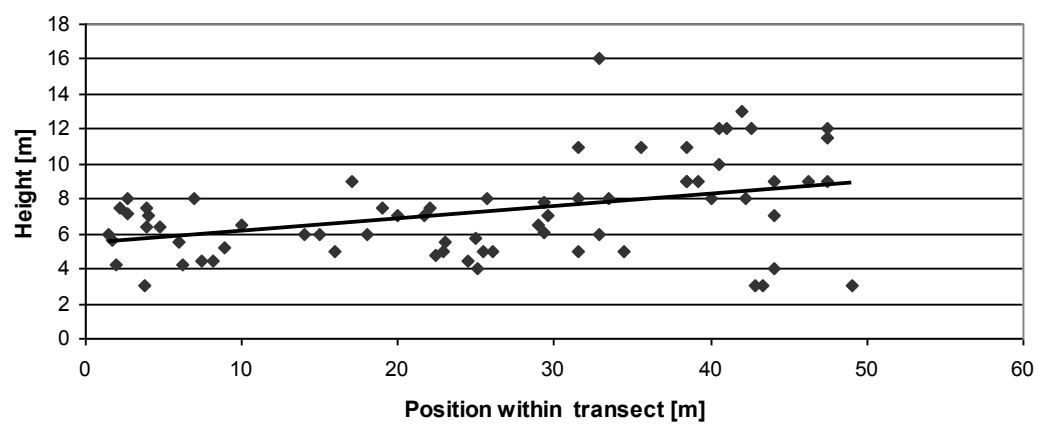

Fig. 4: Dependence of white willow stem girth at breast height on the bank line distance

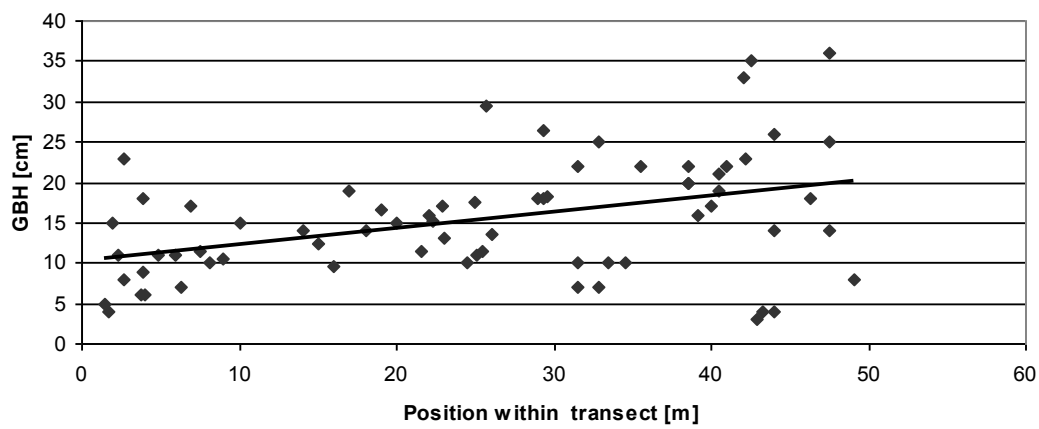

Fig. 5: Correlation of stem diameter and population density of white willow communities

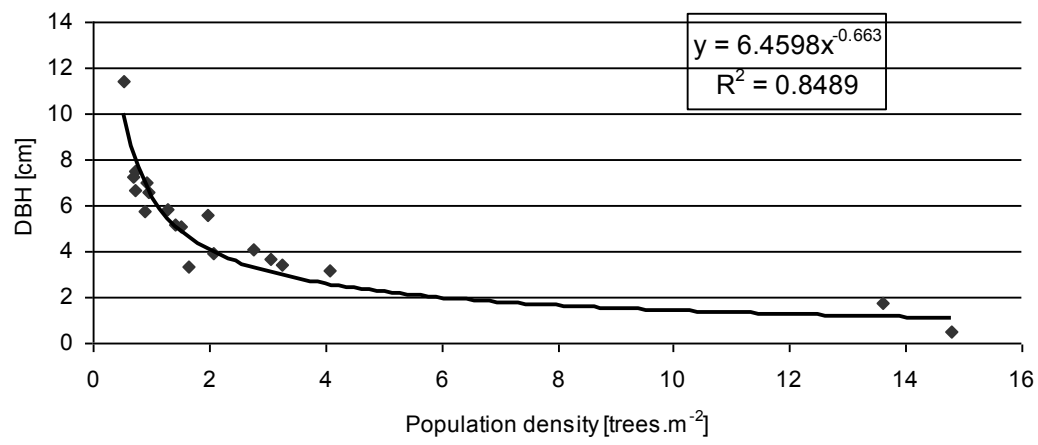


The initial stages of White Willow communities established in primary succession belong to high productive ecosystems (Buček, Maděra, Packová 2004); this is caused by highly fertile alluvial soils, sufficient moisture and long vegetation period. White Willow is a typical pioneer species of the riparian forest ecosystem, R-strategist (Grime 1979) with a fast growth in juvenility.

The high light demands support the height increment, the average annual height increment on the research plots exceeds $1 \mathrm{~m}$ and by highest specimens approachs $2 \mathrm{~m}$. Hydrological conditions influence significantly the rate of growth too. White willow belongs to short rotation species with significant volume increment. Our result reflect very high reserve of dendromass (on av. $150 \mathrm{~m}^{3}$, max. up to $421 \mathrm{~m}^{3}$ ) per hectare at an age of 7 years (age documented also by annual ring analysis).

The community of white willow in the locality produced 45-140 t DM per hectare, which was on average 75 t (Maděra, Packová 2004). The production of DM (without leaves) per hectare per year is $16 \mathrm{t}$, including leaves $16.5 \mathrm{t}$. This value is very favourable exceeding the majority of species which are grown for energy purposes in Central Europe.

White willow is a strongly light-demanding species. Even at high population densities, the stand canopy closeness is relatively low in the crown space, i.e. the stand still transmits a high percentage of radiation $23-47 \%$, on av. $33.6 \%$. This corresponded with the low average LAI of 1.86 whose values on the research plots range from 0.29 to 5.14. Variability of radiation transmittance measured under the stand is higher than radiation measured in the open area this showing that the canopy is not homogeneous but more shaded places rather alternate with crown openings.

The observations of primary succession initial stages of willow-poplar floodplain forests confirmed the high rate of community development. The bioccoridor fulfiled its function very well already in 7 years. It reflects results of floristic survey (̌̌epka 2004). It found 77 herb species, six species of them are mentioned in Red list of endangered plants of the Czech Republic (Holub, Procházka 2000).

\section{DISCUSSION}

\section{Woody plants growth development on former arable land}

The biggest problem whilst planting first bio-corridors in South Moravia was the application of allochthonous woody plants, as mentioned by Jelínek (2011). In the case of the Vracov bio-corridor, the number of allochthonous woody vegetation gradually decreases which is caused by its lower adaptability to climatic conditions and higher light requirements of majority of introduced species. These results are also supported by findings of increasing numbers of allochthonous species at the beginning of the development og a bio-corridor but their gradual decrease on study areas in the course of increasing canopy forming. The growth of cherry trees (Cerasus avium) in the bio-corridor was confirmed as very good; this tendency was earlier mentioned by Úradníček (2004). Among the most common species that are not being planted in bio-corridors but rejuvenate very well belongs Sambucus nigra. This also corresponds with the findings of Jelínek (2011).

\section{Utilisation of succession by revitalisation}

White willow communities occure in the area of the reservoir in a more or less broad strip (up to $60 \mathrm{~m}$ ) along the banks. A similar distribution of tree species seedlings in linear parallel strips along the Waal River in the Netherlands was observed by Van Splunder et al. (1995). Along the Waal R. the seed dispersal occurred in the spring in a following 
sequence: S. viminalis, S. triandra, S. alba and Populus nigra. The seeds germinated in narrow belts parallel to the river; the seedlings of $S$. viminalis were found at a higher altitude than those of $S$. alba. The altitude of seedlings occurring on the river bank was related to the water level during the period of dispersal of Salix spp. but not of Populus. nigra. P. nigra showed a significantly longer seed viability than the Salix species and germinated at a lower soil moisture content.

The ascertained results may be useful for revitalization measures in alluvial plains. If the creation of soft floodplain ecotope occurs at the time of seed rain and the seed source is within the reach, the oecesis of communities will certainly take place instantly. In the case that the period of seed rain is missed, the time for the establishment of communities can be extended by about a month. Then it is however necessary to flood the plots planned for the soft floodplain at the time of seed rain and to subsequently provide for a gradual lowering of the water level development.

The depositions without vegetation were covered by the white willow and black poplar seedlings in autumn. The population density reached as many as 45 specimens per square meter. The seedlings of white willow and black poplar exhibited a further successful development on the denudated sediment loads in 1996 although they might have been exposed to very extreme conditions such as drying out of the boggy substrate. This is supportingthe results presented by Van Splunder et al. (1996) who detected a high drought resistance in the seedlings of white willow and black poplar, which is caused by lower transpiration than for example in almond-leaved willow and osier willow in which a considerable drought-induced mortality was observed. On the other hand, Guilloy et al. (2002) claims that the flooding of black poplar seedlings impairs their capability to surve, which was fully corroborated in the studied area during the July flood in 1997 when black poplar disappeared from most research plots (Buček et al. 2004). Barsoum (2002) recorded a $83 \%$ mortality in one-year old seedlings of black poplar after a summer flood, while the mortality of white willow seedlings was only $52 \%$.

\section{Productivity of early successional stages of White willow communities}

The results prove that the production of the above-ground biomass is very high in the monitored community of the White Willow. In similar study (Madera et al. 2011) the highest average annual values of all monitored production characteristics were achieved at the age of 6 of the stand. The stand had already achieved very high storage $-244.6 \mathrm{~m}^{3} \cdot \mathrm{ha}^{-1}$ - with the mean DBH $5.2 \mathrm{~cm}$ and height $8.5 \mathrm{~m}$, and the drymass production $85 \mathrm{t}^{-\mathrm{ha}^{-1}}$. Moreover, the six-year-old stand reached the highest average annual increment -40.75 $\mathrm{m}^{3} \cdot \mathrm{ha}^{-1} \cdot \mathrm{a}^{-1}$, the average annual production was $16.72 \mathrm{t}^{-h^{-1}} \cdot \mathrm{a}^{-1}$. The estimated value of drymass production is very favourable exceeding the majority of species which are grown for energy purposes in Central Europe. The values exceed the data measured by Bungart et al. (2000) in the region of Lusatia, Germany for 3-4-year-old stands of willows and poplars in mining areas approximately ten times. Kajba et al. (2004) mention that the overall mean DM production of all the investigated clones was 6.5 tons per hectare, the greatest production was exhibited by clones 'B44', 'V093' and 'V052' (10.2, 9.2 and $9.1 \mathrm{t}^{*}$ ha-1, respectively). According to Klimo, Hager (2000) the reserve of dendromass is 200 to 300 $\mathrm{m}^{3}$ per hectare for 25 to 30 years old White Willow stand and $400 \mathrm{~m}^{3}$ per hectare for 40 years old stand in Don and Volga Rivers alluviums.

\section{Creation of missing parts of TSES}

Projects for local, regional and supra-regional territorial systems of ecological stability are gradually being processed all over the Czech Republic. These projects will become an 
integral part of territorial plans, agricultural land-use plans and forest management plans. One of the most demanding tasks is the gradual addition of the missing biocenters and biocorridors. Summarizing data on the current state of creation of new structural elements of TSES in the Czech Republic are still missing. Reseach carried out within the area of the South Moravian region has shown that there had been 62 new lcal bio-centres with the overall area of $256.7 \mathrm{ha}, 38$ local and regional bio-corridors of the total length of $39.1 \mathrm{~km}$ and 29 interaction elements founded (Stránská, Eremiášová 2008).

\section{CONCLUSION}

Interesting is certainly the possibility of using the initial stages of white willow communities for the implementation of energy stands on flood-control polders, making use of their high starting biomass increment rate, high vitality, very good resistance to longterm flooding. At the same time they fulfil a considerable ecostabilizing and corridors functions in the riverine landscape as a native type of plant communities.

In the Czech Republic, there are over 91,000 km watercourses and over 25,000 various water reservoirs. Hydraulic engineering using biological stabilization of riparian banks or the prospective utilization of temporarily flooded areas by suitable willows can represent the indispensable source of energy wood with respect to the engagement of the Czech Republic to increase the proportion of using energy from renewable resources (Maderra et al. 2009). Moreover, yields for the dendromass can at least partly cover costs for the maintenance of bio-technical stabilization of riparian banks.

Based on the monitoring of the growth of woody vegetation in the newly created biocorridors on former agricultural land it is possible to state that the growth of woodland species has been successful. It is necessary to pay attention to protection against browsing and to the choice of autochthonous species, mainly species of shrubs.

It will take several years before new created parts of ecological network begin to fully and positively influence the cultural landscape. And it will take much longer still, certainly several decadess, before the skeleton of ecological stability is succesfully completed so that the territorial systems of ecological stability function as a living ecological network providing good conditions for the existence of natural communities.

\section{ACKNOWLEDGEMENT}

The article was published thanks to a support from the Internal Grant Agency of Faculty of Forestry and Wood Technology Mendel University in Brno (project reg. No. 12/2010), and the Ministry of Education of the Czech Republic (projects LANDTEAM, reg. No. CZ.1.07/2.3.00/20.0004 and MSM 6215648902).

\section{REFERENCES}

Barsoum, N. (2002). Relative contributions of sexual and asexual regeneration strategies in Populus nigra and Salix alba during the 1.rst years of establishment on a braided gravel bed river. Evolutionary Ecology 15, p. 255-279

Bennet, G. (1994). Conserving Europe's natural heritage. Towards a European Ecological Network. (pp. 334). London, Dordrecht, Boston 
Bennet, G. (2004). Integrating biodiversity conservation and sustainable use, lessons learnt from ecological networks. IUCN Gland

Boitani, L., Falcucci, A., Maiorano, L. \& Rondinini, C. (2007). Frameworks or Operational Tools in Conservation. Conservation Biology, 21 (6), p. 1414-1422.

Buček, A., Lacina, J. (1992). Territorial system of landscape ecological stability in the ČSFR. In:Ecological stability of landscape. Proceed. of field workshop (p. 26-31.) FVŽP a IAE VŠZ, Kostelec n. Černýmilesy

Buček, A., Lacina, J. \& Míchal, I. (1996). An ecological network in the Czech Republic. Veronica, Brno. 44 pp.

Buček, A., Lacina, J. (1996). Supraregional territorial system of landscape ecological stability of the former Czechoslovakia. Ekológia Bratislava, 15 (1), p. 71-76

Buček, A., Lacina, J. (1999). Geobiocenologie II. Mendelova zemědělská a lesnická univerzita Brno, 249 pp.

Buček, A., Maděra, P., Kovářová, P. \& Pavlíková, T. (2002). Přeživání dřevin na zaplavených plochách přirodní rezervace Věstonická nádrž. Výzkumná zpráva pro AOPK ČR, Ústav lesnické botaniky, dendrologie a typologie LDF MZLU v Brně MZLU, Brno: 57 pp.

Buček, A., Maděra, P. \& Packová, P. (2004). Hodnocení a predikce vývoje geobiocenóz v PR Věstonická nádrž. Geobiocenologické spisy (sv.č.8, 101 pp.), MZLU v Brně

Bungart, R., Bens, O. \& Hüttl, R.F. (2000). Production of bioenergy in post-mining landscapes in Lusatia. Perspectives and challenges for alternative landuse systems. Ecological Engineering, 16, Supplement 1, p. 5-16.

Culek, M. (1996). Biogeografické členění České republiky. Enigma Praha. 348 s.

Flamiková, J. (1996). Hodnocení a prognóza vývoje krajiny voblasti vodního díla Nové Mlýny. Dipl. práce, MU Brno: 76 str.

Forman, R.T.T. (1983). Corridors in a landscape: their ecological structure and function. Ecology (CSSR), 2, (4), p. 375-387.

Grimme, J.P. (1979). Plant strategies and vegetation processes. J.Weley and Sons, Chichesterm New York, Brisbane, Toronto.

Guilloy-froget, H., Muller, E., Barsoum, N. \& Hughes, F.M.R. (2002). Dispersal, germination, and survival of Populus nigra L. (Salicaceae) in changing hydrologic conditions. Wetlands, 22 (3), p. 478-488.

Holub, J., Procházka, F. (2000). Red list of vascular plants of the Czech Republic. Preslia 72: 187-230.

Chmelař, J., Meusel, W. (1986). Die Weiden Europas. Wittenbreg-Lutherstadt, p.144.

Jedicke, E. (1994). Biotopverbund. Ulmer Verlag Stuttgart. 288 s.

Jelínek, B. (2011). Zhodnocení stavu vybraných biokoridorů na jižní Moravě, zejména jejich dřevinné složky, Disertační práce, MENDELU v Brně, 152 pp.

Jelínek, B., Úradníček, L. (2010). The survival and growth rates of woody vegetation in the man-made Vracov biocorridor during the period of 1993-2007. Journal of Landscape Eecology, 3 (1), p. 5-15

Jongmann, R.H.G. (1998). Promising national and regional approaches. The Pan-European Ecological Network. European nature, 1: 19-22 
Jongman, R.H.G., Pungeti, G.P. (2004). Ecological networks and greenways, concept, design and implementation. Cambridge University Press.

Labaree, J. M. (1992). How Greenways Work. A handbook on ecology. National Park Service and Atlantic Center for the Environment, Ipswich. 48 s.

Kajba, D., Bogdan, S. \& Katicic-trupcevic, I. (2004). White willow biomass production in a short rotation clonal test Drávida. Sumarski-List,128 (9-10), p. 509-515.

Klimo, E., Hager, H. (2000). The floodplain forests in Europe. EFI, Leiden, Boston, Köln, Brill., 268 pp.

Kováŕová, P. (2003). Development of woody species communities in the supraregional biocorridor built in the middle water reservoir of Nové Mlýny. Ekológia (Bratislava), vol. 22, Suplement 2, p. 231-241.

Lammers, G.W., van Zadelhoff, F.J. (1996). The dutch national ecological network. In: P. Nowicki et al. (1996). Perspectives on ecological networks. (p.101-113). European Centre for Nature Conservation

Mackovčin, P. (2000). A multi-level ecological network in the Czech Republic: Implementating the territorial system of ecological stability. GeoJournal, 51( 3), p. 211-220

Maděra, P., Lopéz, D. \& Šenfeldr, M. (2011). The above-Ground Biomass Production and Distribution in White Willow Community during 10 Years of Primary Succession. In.: I. Atazadeh (Ed.), Biomass and Remote Sensing of Biomass. (p. 111-126). InTech

Maděra, P., Packová, P. (2004). Primary succession of white willow communities in the supraregional biocorridor in the middle water reservoir of Nové Mlýny. Ekológia (Bratislava), 23, Suplement 1, p. 191-204.

Maděra, P., Packová, P., Manjarrés, D.R.L., Štykar, J. \& Simanov, V. (2009). The model of potential biomass production in Odra R. basin. Ekológia (Bratislava). 28 (2), p. 170-190.

Maděra, P., Svobodová, I. \& Packová, P. (2009). Oecesis of White Willow Communities in the nature reserve Věstonická nádrž reservoir. Ekológia (Bratislava), 28 (1), p. 7-21.

Maroder, H., Prego, I. \& Maldonado, S. (2003). Histochemical and ultrastructural studies on Salix alba and S. matsudana seeds. Trees - Structure and Function, 17 (3), p. 193-199.

Nowicki, P., Bennett, G., Middleton, D., Rientjes, S. \& Wolters, R. (1996). Perspectives on ecological networks. European Centre for Nature Conservation. $192 \mathrm{~s}$.

Packová, P., Maděra, P. (2005). Změny krajiny v prostoru střední novomlýnské nádrže. Acta Environmentalica Universitatis Comenianae (Bratislava), 13 (1), p. 85-95.

Ružičková, J., Šíbl, J. (2000). Ekologické siete v krajine. Prírodovedecká fakulta UK Bratislava a Slovenská polnohospodárska univerzita Nitra, $182 \mathrm{~s}$.

Řepka, R. (2003). Přehled rostlinných druhů v PR Věstonická nádrž. In.: A. Buček, P. Maděra, Dřeviny v př́rodní rezervaci Věstonická nádrž. (44 p., 2 př́l.). Ústav lesnické botaniky, dendrologie a typologie MZLU, Brno

Smith, D. S., Hellmund, P.C. (1993). Ecology of greenways: design and function of linear conservation areas. University of Minnesota Press, Minneapolis. 214 p.

Stránská, T., Eremiášová, R. (2008). Realizace prvků územních systémů ekologické stability v Jihomoravském kraji. In: A. Petrová, (Ed.): ÚSES - zelená páteř krajiny. Sb. 7. roč. sem. (s. 79), 2008 v Brně. Lesnická práce, Kostelec nad Černými lesy

Úradníček, L. (2004). Evaluation of the Woody Component Development of the Model Biocorridor, Ekológia (Bratislava), vol.23, Supplement 1, p 351-361. 
Van Splunder, I., Coops, H., Voesenek, L.A.C.J. \& Blom C.W.P.M. (1995). Establishment of alluvial forest species in floodplains: the role of dispersal timing, germination characteristics and water level fluctuations. Acta Botanica Neerlandica, 44: 3, p.269-278.

Van Splunder, I., Voesenek, L.A.C.J., Coops, H., De Vries, X.J.A. \& Blom, C.W.P.M. (1996). Morphological responses of seedlings of four species of Salicaceae to drought. Canadian Journal of Botany, 74 (12), p. 1988-1995. 